\title{
ASSESSMENT THE HEALTH- RELATED QUALITY OF LIFE AMONG ENDOMETRIOSIS WOMEN IN MATERNAL AND CHILD HEALTH CENTERS IN DAMIETTA
}

\author{
Prof. Sanaa Ali Nor ${ }^{1}$, Assist.Prof. Seham Shehata Ibrahim², Dr. Gehan Ahmed \\ Elbahlawan $^{3}$, Walaa Hamdy Abd El-Lattif Montaser ${ }^{4}$
}

Prof of Obstetrics and Gynecology, Faculty of Nursing-Zagazig University ${ }^{1}$, Assistant prof of Maternity, Obstetric and Gynecological Nursing, Faculty of Nursing - Port said University ${ }^{2}$, Lecturer of Maternity, Obstetric and Gynecological Nursing, Faculty of Nursing - Port said University ${ }^{3}$.

\begin{abstract}
Background: Endometriosis is a disease affect Women' health and Quality of life especially in child bearing age. Aim: Assess the Health- Related Quality of life among Endometriosis Women in Maternal and Child Health Centers in Damietta. Design: A descriptive study was used. Setting: Gynecology and Obstetrics out patient at three Maternal and Child Health centers; New Damietta MCH center, Shata MCH center and Kafer Shehata MCH center in Damietta city. Subjects: A total of 100 women with surgically diagnosed endometriosis were purposively selected. Tools: Include; structured interviewing questionnaire and the Endometriosis Health Profile (EHP-30+5). Results: shows that $83.0 \%$ of women had infertility. There was a delay in seeking treatment that ranged between 2-10 years. Endometriosis had a negative impact on woman's quality of life and there is statistically significant relation between stages of endometriosis and the negative aspect of women's quality of life in terms of physical, psychological, sexual, educational and working life. Recommendations: there is a need for teaching patients to avoid the delay in seeking treatment. As well as how to cope with chronic pelvic pain and to teach patients how to strengthen relationships with their partner and friends, so they will be supportive in coping with the disease instead of drifting apart due to potential misunderstandings. Conclusion: There was a delay in seeking treatment for endometriosis despite its negative impact on woman's quality of life in terms of physical, psychological, sexual, educational and working life.
\end{abstract}

Key words: Endometriosis Women, Health- Related Quality of life, Maternal and Child Health Centers. 


\section{INTRODUCTION}

Endometriosis is a disease characterized by the presence of endometrium-like epithelium and stroma outside the endometrium and myometrium. Intrapelvic endometriosis can be located superficially on the peritoneum (peritoneal endometriosis), can extend $5 \mathrm{~mm}$ or more beneath the peritoneum (deep endometriosis) or can be present as an ovarian endometrial cyst (endometrioma). Endometriosis symptoms include; severe dysmenorrhea, deep dyspareunia, chronic pelvic pain, ovulation pain, cyclical or perimenstrual symptoms (e.g. bowel or bladder associated) with or without abnormal bleeding, infertility, chronic fatigue. The predictive value of any one symptom or set of symptoms remains uncertain as each of these symptoms can have other causes (and a significant proportion of affected women are asymptomatic) Adamson, (2016).

In fact, prevalence rates of endometriosis vary widely from study to study, depending on the population surveyed. The estimated prevalence of endometriosis of American women of childbearing age is between $10 \%$ and $15 \%$. Because surgical confirmation is necessary for the diagnosis of endometriosis, the true prevalence of the disease is unknown. It is found almost exclusively in women of reproductive age, and is the single most common reason for hospitalization of women in this age group. Approximately $20 \%$ of women with chronic pelvic pain and $30 \%$ to $40 \%$ of women with infertility have endometriosis (Callahan\& Caughey, 2013).

Endometriosis reduces the quality of life of women and most are absent at work due to pain. Severe pain and dyspareunia predict loss in social and sexual aspects of life, such as reduced quality of life and lost productivity at work, accounting for nearly $60 \%$ loss of productivity at work. The typical endometriosis triad (dyspareunia, dysmenorrhea and infertility) has a direct impact on the lives of women in different areas, whether social, sexual, physical or psychological. Pain has a cyclic nature and is, therefore, repeated and prone to worsening condition in every cycle, interfering with women's health from a holistic point of view (Vercellini et al., 2011).

\section{SIGNIFICANCE OF STUDY:}

Endometriosis affects an estimated 1 in 10 women during their reproductive years. Meanwhile, 176 million women worldwide were affected during the prime years of their lives Adamson, (2016). Endometriosis prevalence and severity are reportedly increasing in developing countries. It is a fatal problem, which needs a tangible effort in order to minimize this prevalence and help those patients with endometriosis to lead a better quality of life. It affects the everyday lives of women, hindering their daily activities, in personal relationships, 
and interferes with the reproductive capacity. Because of its negative impact on the quality of women's life in terms of pain and infertility and the economic burden for diagnosis, pharmacologic and surgical treatments, as well as for assisted fertilization practice, endometriosis has been recognized as a health priority. Maternity nurses should be aware of this issue in order to adequately assist women with endometriosis in coping with this problem. Since there are few qualitative studies about endometriosis and its impact on woman's life therefore, this study was be done to assess the Health- Related Quality of life among Endometriosis Women in Maternal and Child Health Centers in Damietta.

\section{AIM OF STUDY:}

The aim of the present study was to; assess the Health- Related Quality of life among Endometriosis Women in Maternal and Child Health Centers in Damietta.

\section{SUBJECTS AND METHOD:}

\section{A. Technical design:}

This design covers the research design, settings, subjects and tools of data collection.

\section{Research design:}

A descriptive design was used for this study to achieve the stated aim.

\section{Study setting:}

The present study was carried out in the Obstetrics and Gynecological outpatient at three Maternal and Child Health centers (New Damietta MCH center, Shata MCH center, Kafer Shehata MCH center) in Damietta city, this gave the chance to the researcher to collect necessary information.

\section{Study sample:}

A purposive sample of 100 women diagnosed with endometriosis who attended the study setting and fulfilling the following inclusion were recruited for this study.

\section{Inclusion criteria:}

- Women with a confirmed diagnosis of endometriosis (via laparoscopy).

- Free from other chronic disease.

- Woman accept to participate in the study.

\section{Tools of data collection:}

Tool (I): A structured interviewing schedule.

It was designed, tested for validity and reliability and utilized by researcher to collect the necessary data. It entailed two parts: 
Part I. This includes; Personal and socio-demographic characteristics about the study subjects such as (age, level of education and occupation, etc). Menstrual history: which include age of menarche, regularity, amount of menstrual blood, duration of bleeding and presence of dysmenorrhea. Obstetric history such as gravida, Para, abortions,...etc.). A detailed medical, surgical, family and gynecological history were also obtained. Data related to the diseased condition such as the onset of endometriosis, symptoms encountered, the delay in diagnosis and treatment prescribed. Patient knowledge and experience with endometriosis.

\section{Tool (II): Endometriosis Health Profile:}

The Endometriosis Health Profile is a Health Related Quality of Life (HRQoL) patient self- report; used to measure the wide range of effects that endometriosis can have on women's life. This was modified by the researcher to answer the previously mentioned research questions.

It covers: The effect of endometriosis on the Physical, Psychological, Sexual, employment and the educational life.

\section{Scoring system:}

The impact of endometriosis on the quality of life on the women was estimated by a questionnaire included 35 items. The responses on these items were recorded on 3-point scale from 1 (rare) to 3 (often). The questionnaire evaluated 5 domains: the impact of endometriosis on physical condition (7 questions), impact of endometriosis on psychological condition (13 questions), impact of endometriosis on sexual relationship (4 questions), impact of endometriosis on education (5 questions) and impact of endometriosis on work (6 questions). The score of each domain is the sum of scores of individual items of each domain. The scores were then dichotomized into two categories; $<60 \%$ indicate little impact and $>60 \%$ indicate greater impact on the domain.

\section{Administrative design:}

An official permission was granted by submission of an official letter from the Faculty of Nursing to the responsible authorities of the study setting (Director of Maternal and Child Health Centers in Damietta) to obtain their permission for data collection.

\section{Operational design:}

The operational design includes preparatory phase, tools validity, reliability, pilot study and fieldwork. 


\section{Preparatory phase:}

The preparatory phase aimed to prepare the tools used in data collection. During this phase, the researcher reviewed local and international literature, different studies and theoretical knowledge of various aspects of the research topic using books, articles, internet, periodicals and magazines to get more knowledge about the study subject. This also helped in designing the study tools.

\section{Tools validity:}

Five experts in the field of obstetrics and gynecological nursing and medicine tested the tools for content validity. The recommended modifications were done and the final form was ready for use.

\section{Reliability:}

Alpha Cronbach reliability analysis for the study tool was done. It revealed that question statement of the tool were relevance.

\section{Pilot study:}

The pilot study was carried out over a period of one month. It was conducted on $10 \%$ of the total sample size to evaluate the reliability and applicability of tools and to estimate the proper time required for answering the questionnaire. Necessary modifications were carried out as revealed from the pilot study. The study tool was revised, redesigned and rewritten according to obtained results and acceptance of final form.

\section{Field of work:}

Data collected through a period of six months from the beginning of December 2016 to the end of May 2017. The researcher started the data collection during the six days of the week. Six days were permitted for each $\mathrm{MCH}$ center alternately. The researcher interviewed women who either they came for further investigations and treatment or for following up.

The investigator attended the gynecological outpatient at the studied setting; Six days were permitted for each $\mathrm{MCH}$ center alternately during the period of six months. Every woman was asked about the socio-demographic data, menstrual history, obstetric history, gynecological history, family history for endometriosis, present medical history. Patients complain and symptoms encountered, her knowledge about endometriosis, her experience with health provider, her opinion about the effect of endometriosis symptoms on her life was also taken. 
Endometriosis Quality Health Profile was used to assess the effect of endometriosis on the Physical, Psychological, Sexual, employment and the educational life of the patient. I read each statement for the woman and record her feeling or answer she said. .

Medical records for patients with endometriosis were obtained and reviewed in detail to obtain data pertaining to the operative report. This revealed the accurate diagnosis of the woman, the stage of endometriosis she has, her age at diagnosis, date of previous laparoscopy if she come for following up, the medical, obstetrical and gynaecological history.....etc.

The final form of a structured interviewing questionnaire sheet which used by the researcher to collect data from the study subjects conducted in total privacy. Personal interview was done at the gynecological outpatient for each woman with endometriosis and it takes 30 minutes for each one.

As for the limitation of the study, the sample size was too small together with the inability to perform statistical equation to select the study sample, because the low rate of women attendance according to the previously mentioned inclusion criteria. This affected the generalization of the results; however, it gave an overview about the impact of endometriosis on women quality of life.

\section{D) Statistical design:-}

All statistical analyses were performed using SPSS for windows version 20.0 (SPSS, Chicago, IL). Continuous data were expressed in mean \pm standard deviation (SD) while categorical data were expressed in number and percentage. The comparisons of variables with categorical data were determined using chi-square test. Statistical significance was set at $\mathrm{p}<0.05$.

\section{RESULTS:}

Table (1): Presents distribution of the studied women according to their sociodemographic characteristics. It revealed that women age ranged between $19-40$ years, with a mean age of $29.1 \pm 4.8$ years and the highest percentage $(70.0 \%)$ was between 25 - 35 years of age. More than half $(52.0 \%)$ of the studied women was highly educated, the majority was married and working women (84.0\% and $56.0 \%$ respectively). The monthly income was not enough for most of them $(74.0 \%)$ and one fifth $(20.0 \%)$ of them had family history of endometriosis.

Table (2): shows the distribution of the studied women according to their clinical picture. More than two thirds $(62.0 \%)$ of the studied women suffered from both cyclic and 
acyclic pelvic pain. Meanwhile, 58.0\% had dyspareunia during and after the intercourse. Dysuria, dyschezia and post-coital bleeding were encountered by $20.0 \%, 13.6 \%$ and $11.0 \%$ of them respectively. In addition, there is $(83.0 \%)$ had history of infertility which ranges in

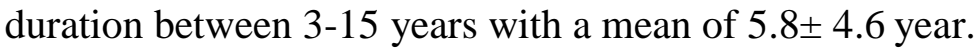

Figure (1): illustrates the stages given for the diagnosis of the endometrioses, the majority had stage II "moderate", followed by stage III "severe" and the rest was in the stage I "mild endometriosis $(69.0 \%, 17.0 \%$ and $14.0 \%$ respectively).

Table (3): presents patient's experience with the disease. The mean age at onset of endometriosis was $20.4 \pm 4.3$ and the majority $(86.0 \%)$ had an early onset of the disease $(<25$ years). There was a delay of 2- 10 years, between onset of symptoms and a surgical diagnosis of endometriosis, with a mean of $5.7 \pm 1.6$. The delay in seeking treatment was $\leq 5$ years in $35.0 \%$ and $\geq$ in $65.0 \%$. Very few women who were satisfied with the treatment they received and the majority (74.0\%) had insufficient knowledge about endometriosis.

Table (4): shows that endometriosis has a negative impact on the physical life of the studied women (79.0\%). Physical limitations in terms of; body movement, anorexia, doing home-work, taking care of their children because of pain, was noticed sometimes and frequently in most of the studied sample $(71.0 \%, 74.0 \%, 75.0 \%$ and 79.0 respectively).

Table (5): It is obvious from it that endometriosis had a negative impact on the psychological life of the studied women $(75.0 \%)$. Almost three quarters of the studied women felt frustrated because their symptoms are not getting better, being inadequate and depressed at the possibility of not having children as well as had the feeling of depression, anxiety and feelings of low self-esteem. This was noticed sometimes and frequently in most of the studied sample $(74.0 \%, 77.0 \%$ and $79.0 \%$ respectively).

Table (6): shows that dyspareunia has a great negative impact on the sexual life for more than two thirds $(67.4 \%)$ of the studied women. The majority were suffered usually or sometimes from the feeling of guilty or frustration because of avoiding intercourse or being unhappy with it $(76.6 \%$ and $75.6 \%$ respectively).

Table (7): point to the negative impact of endometriosis on women's educational life which present in more than three fourths $(75.3 \%)$ of the studied women. This was mostly noticed in the variables of taking frequent sick leaves, poor concentration and carrying out school duties (69.7\% and $70.0 \%$ respectively).

Table(8): presents that endometriosis had a great negative impact on women's work lives $(73.3 \%)$. Nearly three quarters $(74.4 \%)$ of them had sometimes or usually take time off 
work because of pain, causing women to feel guilty and embarrassed because of loss productivity.

Table (9): shows that there is statistically significance relation between stages of endometriosis and the negative aspect of women's quality of life in terms of physical, psychological, sexual, educational and working life.

Table (1): Distribution of the studied women according to their socio-demographic characteristics.

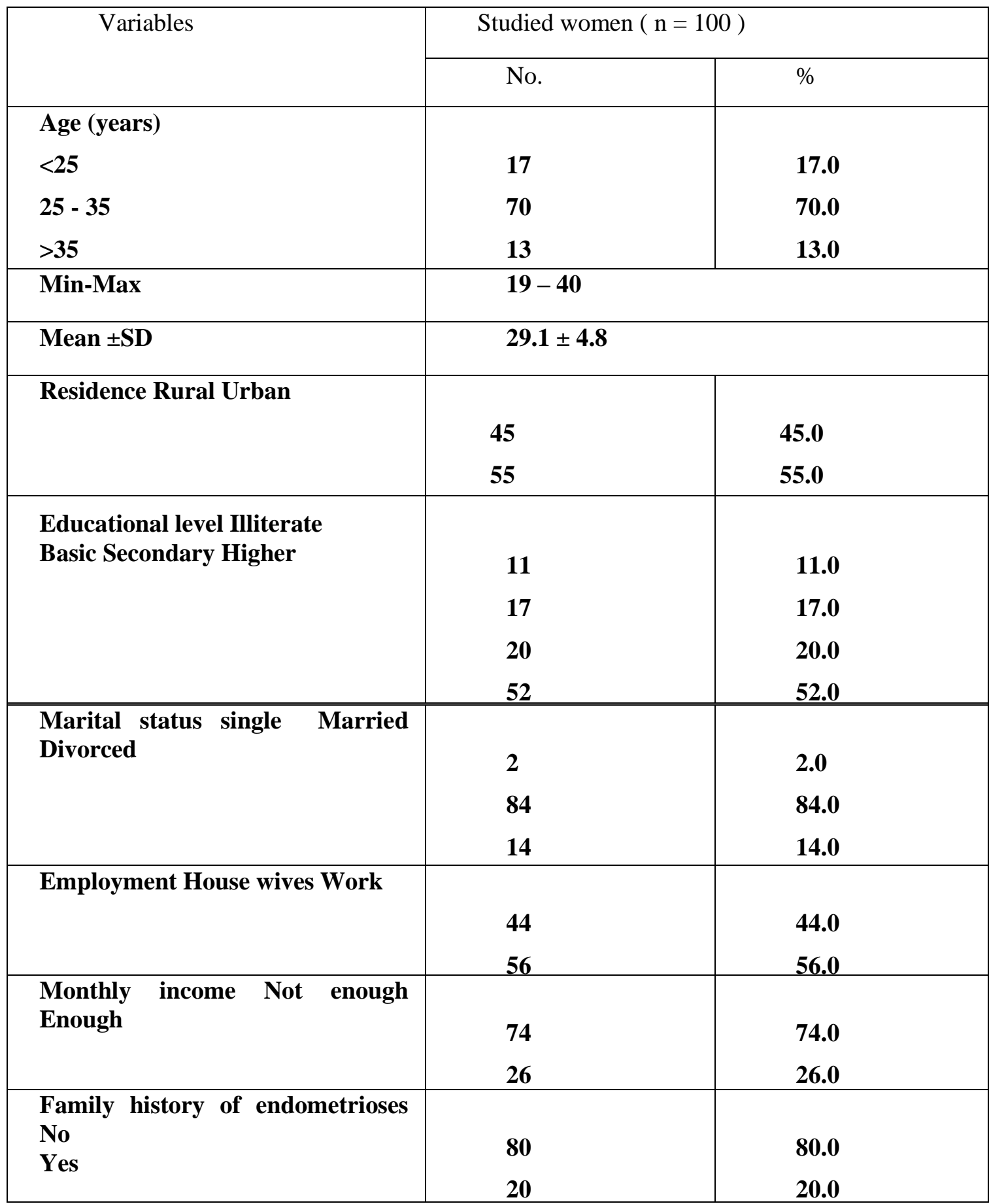


Table (2): Distribution of the studied women according to their clinical picture $(n=100)$

\begin{tabular}{|c|c|c|}
\hline Variables & $\mathrm{N}$ & $\%$ \\
\hline $\begin{array}{l}\text { Pain } \\
\text { Both cyclic and acyclic pain Cyclic pain } \\
\text { Acyclic pain }\end{array}$ & $\begin{array}{l}62 \\
10 \\
28\end{array}$ & $\begin{array}{l}62.0 \\
10.0 \\
28.0\end{array}$ \\
\hline $\begin{array}{l}\text { Dyspareunia (n=138) } \\
\text { Dyspareunia during and after intercourse } \\
\text { Dyspareunia during intercourse Dyspareunia } \\
\text { after intercourse Dyspareunia all the month }\end{array}$ & $\begin{array}{l}80 \\
12 \\
25\end{array}$ & $\begin{array}{l}58.0 \\
8.7 \\
18.1\end{array}$ \\
\hline $\begin{array}{l}\text { Urinary problems } \\
\text { Supra-pubic pain } \\
\text { Combination of urgency \& urinary frequency }\end{array}$ & $\begin{array}{l}15 \\
20\end{array}$ & $\begin{array}{l}15.0 \\
20.0\end{array}$ \\
\hline $\begin{array}{l}\text { Digestive problems (n=125) Dyschezia during } \\
\text { menses Constipation lasting for days Diarrhea } \\
\text { Abdominal cramping }\end{array}$ & $\begin{array}{l}17 \\
23 \\
30\end{array}$ & $\begin{array}{l}13.6 \\
18.4 \\
24.0\end{array}$ \\
\hline $\begin{array}{l}\text { Abnormal bleeding Blood in urine or stool } \\
\text { Post-coital bleeding }\end{array}$ & 2 & 2.0 \\
\hline Infertility & 83 & 83 \\
\hline $\begin{array}{l}\text { Duration of infertility }(\mathrm{n}=83) \\
<5 \text { years } \\
5-10 \text { years }\end{array}$ & 25 & 30.1 \\
\hline
\end{tabular}




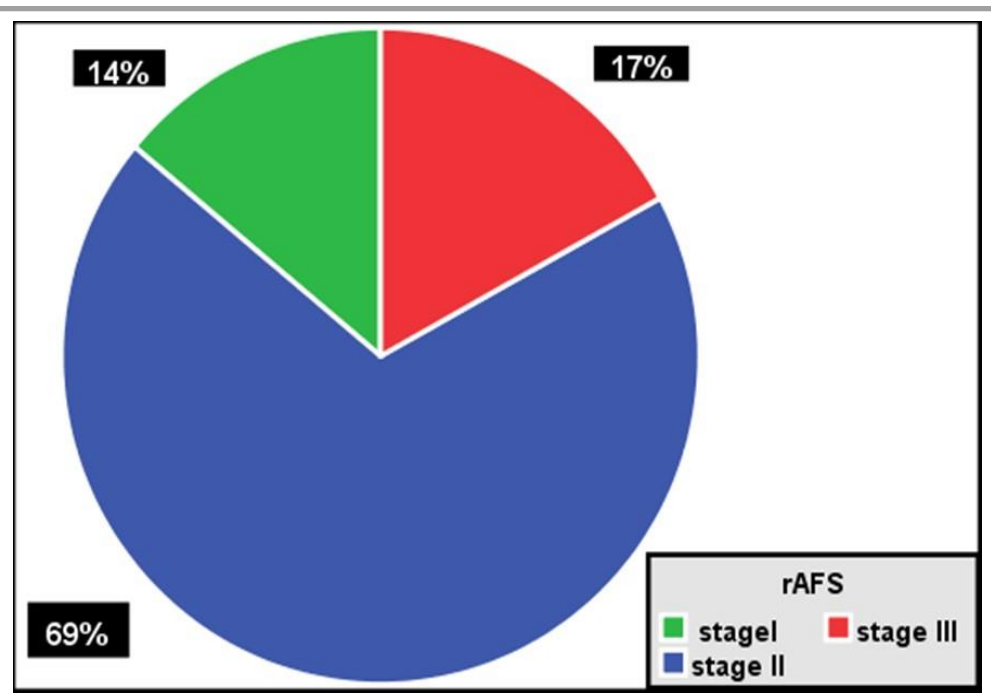

Figer (1): Stages given for the diagnosis of the endometrioses

Table (3): Distribution of the studied women according to their experience with the disease $(n=100)$

\begin{tabular}{|c|c|c|}
\hline Variables & No. & $\%$ \\
\hline Age at onset & \multirow{3}{*}{86} & \\
\hline$<25$ & & 86.0 \\
\hline$>25$ & & 14.0 \\
\hline Min-Max & \multicolumn{2}{|l|}{$14-31$} \\
\hline Mean \pm SD & \multirow[t]{2}{*}{$20.4 \pm 4.3$} & \\
\hline Delay of diagnosis & & \\
\hline$\leq 5$ & 35 & 35 \\
\hline Min-Max & \multicolumn{2}{|l|}{$2-10$} \\
\hline Mean \pm SD & \multicolumn{2}{|l|}{$5.7 \pm 1.6$} \\
\hline \multirow{4}{*}{$\begin{array}{l}\text { Treatment satisfaction } \\
\text { Never Little Moderate }\end{array}$} & & \\
\hline & 49 & 49 \\
\hline & 39 & 39 \\
\hline & 12 & 12 \\
\hline \multirow{2}{*}{$\begin{array}{ll}\text { Knowledge } & \text { about } \\
\text { endometriosis } & \\
\text { Insufficient Sufficient } & \end{array}$} & 74 & 74 \\
\hline & 26 & 26 \\
\hline
\end{tabular}


Table (4): Distribution of the studied women according to the impact of endometriosis on women physical life $(n=100)$

\begin{tabular}{|l|l|l|l|}
\hline $\begin{array}{l}\text { How Often, Because Of Your } \\
\text { Endometriosis, Have You... }\end{array}$ & $\begin{array}{l}\text { Rometimes } \\
(\%)\end{array}$ & Often (\%) \\
\hline $\begin{array}{l}\text { Found difficulty in doing body movements as } \\
\text { (walking -sitting - standing) because of the } \\
\text { pain? }\end{array}$ & 29.0 & 48.0 & 23.0 \\
\hline $\begin{array}{l}\text { Lost your appetite and/or been unable to eat } \\
\text { because of the pain? }\end{array}$ & 26.0 & 40.0 & 34.0 \\
\hline $\begin{array}{l}\text { Been unable to sleep properly because of } \\
\text { the pain? }\end{array}$ & 36.0 & 37.0 & 27.0 \\
\hline $\begin{array}{l}\text { Been unable to do jobs around the home } \\
\text { because of the pain? }\end{array}$ & 25.0 & 38.0 & 37.0 \\
\hline $\begin{array}{l}\text { Found it difficult to take care of yourself and } \\
\text { your dressing? }\end{array}$ & 35.0 & 30.0 & 35.0 \\
\hline $\begin{array}{l}\text { Found it difficult to look after your child/ } \\
\text { children? (n=38) }\end{array}$ & 21.0 & 50.0 & 29.0 \\
\hline $\begin{array}{l}\text { Been unable to do the leisure activities you } \\
\text { would like to do because of the pain? }\end{array}$ & 40.0 & 31.0 & 29.0 \\
\hline $\begin{array}{l}\text { Total score: } \\
\text { Little impact: positive<60\% Great impact: } \\
\text { negative >60\% }\end{array}$ & \multicolumn{2}{|c|}{$\mathbf{7 9}$} \\
\hline
\end{tabular}


Table (5): Distribution of the studied women according to the impact of endometriosis on women psychological life $(\mathrm{n}=100)$

\begin{tabular}{|l||l||l||c||}
\hline $\begin{array}{l}\text { How Often, Because Of Your } \\
\text { Endometriosis, Have You... }\end{array}$ & Rare (\%) & Sometimes (\%) & Often (\%) \\
\hline \hline $\begin{array}{l}\text { Felt frustrated because your symptoms } \\
\text { are not getting better? }\end{array}$ & 26.0 & 34.0 & 40.0 \\
\hline $\begin{array}{l}\text { Felt frustrated because you are not able to } \\
\text { control your symptoms? }\end{array}$ & 29.0 & 37.0 & 34.0 \\
\hline $\begin{array}{l}\text { Felt inadequate because you may not / } \\
\text { have not been able to have children/more } \\
\text { children? }\end{array}$ & 29.0 & 35.0 & 36.0 \\
\hline \hline $\begin{array}{l}\text { Felt depressed at the possibility of not } \\
\text { having children/more children? }\end{array}$ & 23.0 & 37.0 & 40.0 \\
\hline $\begin{array}{l}\text { Felt worried about the possibility of not } \\
\text { having children/more children? }\end{array}$ & 23.0 & 37.0 & 40.0 \\
\hline Feeling of depression \&anxiety? & 21.0 & 40.0 & 39.0 \\
\hline \hline Felt miserable? & 24.0 & 35.0 & 41.0 \\
\hline Had mood swings? & 37.0 & 35.0 & 28.0 \\
\hline Felt violent or aggressive? & 35.0 & 28.0 & 37.0 \\
\hline Lacked confidence? & 31.0 & 34.0 & 45.0 \\
\hline Felt unable to tell people how & 26.0 & 33.0 & 41.0 \\
\hline $\begin{array}{l}\text { Felt your symptoms are taking } \\
\text { away your life? }\end{array}$ & 29.0 & 43.0 & \\
\hline \hline 13) Felt alone? & $\mathbf{2 5}(\mathbf{2 5 . 0 \% )}$ & \\
\hline \hline $\begin{array}{l}\text { Total score: } \\
<60 \% \\
\geq 60 \%\end{array}$ & $\mathbf{7 5 . 0 \% )}$ & \\
\hline
\end{tabular}

Table (6): Distribution of the studied women according to the impact of endometriosis on women sexual life $(n=98)$

\begin{tabular}{|c|c|c|c|}
\hline $\begin{array}{l}\text { How Often, Because Of Your } \\
\text { Endometriosis, Have You... }\end{array}$ & $\begin{array}{l}\text { Rare No. } \\
(\%)\end{array}$ & $\begin{array}{l}\text { Sometimes No. } \\
(\%)\end{array}$ & $\begin{array}{l}\text { Often } \\
\text { No. } \\
(\%)\end{array}$ \\
\hline $\begin{array}{l}\text { Felt worried about having intercourse because of } \\
\text { the pain? }\end{array}$ & $\begin{array}{c}29 \\
(29.7 \%) \\
\end{array}$ & $\begin{array}{c}32 \\
(32.6 \%) \\
\end{array}$ & $\begin{array}{c}37 \\
(37.7 \%) \\
\end{array}$ \\
\hline Avoided intercourse because of the pain? & $\begin{array}{c}32 \\
(32.6 \%) \\
\end{array}$ & $\begin{array}{c}33 \\
(33.7 \%) \\
\end{array}$ & $\begin{array}{c}33 \\
(33.7) \\
\end{array}$ \\
\hline Felt guilty about not wanting to have intercourse? & $\begin{array}{c}23 \\
(23.4 \%) \\
\end{array}$ & $\begin{array}{c}29 \\
(29.7 \%) \\
\end{array}$ & $\begin{array}{c}46 \\
(46.9 \%) \\
\end{array}$ \\
\hline $\begin{array}{lllll}\text { Felt frustrated because you cannot enjoy } \\
\text { intercourse? }\end{array}$ & $\begin{array}{c}24 \\
(24.4 \%) \\
\end{array}$ & $\begin{array}{c}40 \\
(40.8 \%) \\
\end{array}$ & $\begin{array}{c}34 \\
(34.8 \%) \\
\end{array}$ \\
\hline $\begin{array}{l}\text { Total score: } \\
<60 \% \\
>60 \%\end{array}$ & $\begin{array}{ll}32 & (3 \\
66 & (6\end{array}$ & $\begin{array}{l}6 \%) \\
4 \%)\end{array}$ & \\
\hline
\end{tabular}


Table (7): Distribution of the studied women according to the impact of endometriosis on women educational life $(\mathrm{n}=89)$

\begin{tabular}{|c|c|c|c|}
\hline $\begin{array}{l}\text { How Often, Because Of Your Endometriosis, } \\
\text { Have You... }\end{array}$ & $\begin{array}{l}\text { Rare No. } \\
(\%)\end{array}$ & $\begin{array}{l}\text { Sometimes } \\
\text { No. }(\%)\end{array}$ & $\begin{array}{l}\text { Often No. } \\
\quad(\%)\end{array}$ \\
\hline $\begin{array}{l}\text { Had to take time off school /university because } \\
\text { of the pain? }\end{array}$ & $\begin{array}{c}27 \\
(30.3)\end{array}$ & $\begin{array}{c}33 \\
(37 \%)\end{array}$ & $\begin{array}{c}29 \\
(32.7 \%)\end{array}$ \\
\hline $\begin{array}{l}\text { Felt guilty about taking time off school } \\
\text { /university because of the pain? }\end{array}$ & $\begin{array}{c}24 \\
(27.1 \%)\end{array}$ & $\begin{array}{c}38 \\
(42.6 \%)\end{array}$ & $\begin{array}{c}27 \\
(30.3 \%)\end{array}$ \\
\hline $\begin{array}{l}\text { Been unable to concentrate and study because of } \\
\text { pain? }\end{array}$ & $\begin{array}{c}26 \\
(29.2 \%)\end{array}$ & $\begin{array}{c}34 \\
(38.1 \%)\end{array}$ & $\begin{array}{c}29 \\
(32.7 \%)\end{array}$ \\
\hline $\begin{array}{l}\text { Been unable to carry out duties at school } \\
\text { /university because of the pain? }\end{array}$ & $\begin{array}{c}33 \\
(37 \%)\end{array}$ & $\begin{array}{c}29 \\
(32.7 \%)\end{array}$ & $\begin{array}{c}27 \\
(30.3 \%)\end{array}$ \\
\hline $\begin{array}{l}\text { Felt embarrassed about symptoms at school } \\
\text { /university? }\end{array}$ & $\begin{array}{c}35 \\
(39.3 \%)\end{array}$ & $\begin{array}{c}23 \\
(25.8 \%)\end{array}$ & $\begin{array}{c}31 \\
(34.9 \%)\end{array}$ \\
\hline Total score: & \multicolumn{3}{|c|}{22} \\
\hline$>60 \%$ & & $67 \quad(75.3 \%)$ & \\
\hline
\end{tabular}

Table (8): Distribution of the studied women according to the impact of endometriosis on women working life $(\mathrm{n}=56)$

\begin{tabular}{|c|c|c|c|}
\hline $\begin{array}{l}\text { How Often, Because Of Your Endometriosis, } \\
\text { Have You... }\end{array}$ & $\begin{array}{l}\text { Rare No. } \\
(\%)\end{array}$ & $\begin{array}{l}\text { Sometimes } \\
\text { No. }(\%)\end{array}$ & $\begin{array}{l}\text { Often No. } \\
(\%)\end{array}$ \\
\hline Had to take time off work because of the pain? & $\begin{array}{c}14 \\
(25 \%)\end{array}$ & $\begin{array}{c}25 \\
(44.6 \%)\end{array}$ & $\begin{array}{c}17 \\
(30.4 \%)\end{array}$ \\
\hline Felt guilty about taking time off work? & $\begin{array}{c}12 \\
(21.4 \%)\end{array}$ & $\begin{array}{c}18 \\
(32.2 \%)\end{array}$ & $\begin{array}{c}26 \\
(46.4 \%)\end{array}$ \\
\hline $\begin{array}{l}\text { Been unable to do things you want to do because } \\
\text { of pain? }\end{array}$ & $\begin{array}{c}16 \\
(28.6 \%)\end{array}$ & $\begin{array}{c}20 \\
(35.7 \%)\end{array}$ & $\begin{array}{c}20 \\
(35.7 \%)\end{array}$ \\
\hline $\begin{array}{l}\text { Been unable to carry out duties at work because } \\
\text { of the pain? }\end{array}$ & $\begin{array}{c}12 \\
(21.4 \%)\end{array}$ & $\begin{array}{c}21 \\
(37.5 \%)\end{array}$ & $\begin{array}{c}23 \\
(41.1 \%)\end{array}$ \\
\hline Felt embarrassed about symptoms at work? & $\begin{array}{c}19 \\
(33.9 \%)\end{array}$ & $\begin{array}{c}21 \\
(37.5 \%)\end{array}$ & $\begin{array}{c}16 \\
(28.6 \%)\end{array}$ \\
\hline $\begin{array}{l}\text { Felt worried about not being able to do your } \\
\text { job? }\end{array}$ & $\begin{array}{c}17 \\
(30.4 \%)\end{array}$ & $\begin{array}{c}20 \\
(35.7 \%)\end{array}$ & $\begin{array}{c}19 \\
(33.9 \%)\end{array}$ \\
\hline $\begin{array}{ll}\text { Total score: } & <60 \% \\
& \geq 60 \%\end{array}$ & $\begin{array}{l}15(26.7 \%) \\
41(73.3 \%)\end{array}$ & & \\
\hline
\end{tabular}


Table (9): the relation between the level of negative impact and the stages of the disease:

\begin{tabular}{|c|c|c|c|c|c|c|}
\hline \multirow{3}{*}{$\begin{array}{l}\text { Quality of life domains } \\
\text { “Negative aspect” } \\
\quad \geq 60 \%\end{array}$} & \multicolumn{6}{|c|}{ stages of endometriosis } \\
\hline & \multicolumn{2}{|c|}{$\begin{array}{c}\text { Moderate and } \\
\text { severe }\end{array}$} & \multicolumn{2}{|c|}{ Mild } & \multicolumn{2}{|c|}{ Chi square test } \\
\hline & No. & $\%$ & No. & $\%$ & $\mathrm{X} 2$ & $\overline{\mathbf{P}}$ \\
\hline Physical domain $(n=79)$ & 75 & 87.2 & 4 & 28.6 & 36.208 & $<0.001$ \\
\hline Psychological domain $(n=75)$ & 75 & 87.2 & 0 & 0.00 & 92.120 & $<0.001$ \\
\hline Sexual domain $(n=66)$ & 65 & 76.5 & 1 & 7.7 & 46.697 & $<0.001$ \\
\hline Educational life $(n=67)$ & 64 & 84.2 & 3 & 23.1 & 38.090 & $<0.001$ \\
\hline Working life $(n=41)$ & 40 & 83.3 & 1 & 12.5 & 25.497 & $<0.001$ \\
\hline
\end{tabular}

\section{DISCUSSION:}

Endometriosis is a chronic disease, which is underdiagnosed, under-reported, and underresearched (Gao et al., 2006). It is defined as the presence of the functional endometrial glands and stroma, which are normally part of the innermost lining of the uterine cavity (the endometrium), outside the uterine cavity. Adenomyosis means the presence of endometrial tissue inside the myometrium (Dunselman et al., 2014).

The prevalence has been reported around $10 \%$ of the general female population and $20-90 \%$ in women with pelvic pain or infertility (Wolman, 2014). However, the etiology and pathogenesis is not known with certainty (Sourial et al., 2014). Endometriosis is often labeled 'the missed disease', there is no cure for it, its economic burden is high and no guarantee that it will not return (Denny \& Mann, 2007). Nnoaham et al., (2011) study identified impaired health related quality of life and work productivity across countries and ethnicities, yet women continue to experience delay in diagnosis.

Therefore, the present study was conducted to explore women's experience of endometriosis and its impact, on woman's quality of life.

The present study finding revealed that the highest percentage of women age was between 25-35 years. They were mostly working and highly educated. In the same line El-Maraghy et al., study (2017) in Egypt found that endometriosis generally affects women during the most productive years of their lives, when they should be finishing education, starting a career and probably have a family. 
The current study revealed that there is one fifth of women had family history for endometriosis, this go with the finding of Mamdouh et al., study (2011) in a hospital-based casecontrol study about Epidemiologic determinants of endometriosis among Egyptian women. They found that women who had one or more relatives with endometriosis were more likely to develop endometriosis. Similarly, Rogers, study (2013) to define future directions for endometriosis research in France, confirmed that this disease is a genetic disorder of polygenic/multifactorial inheritance. The disorder has long been recognized to show heritable tendencies with recurrent risks of 5-7\% for first-degree relatives.

Regarding the menstrual characteristics of the studied women the present finding revealed that more than half of them had early menarche. The majority of women suffered from dysmenorrhea and sizable number were exposed to menorrhagia, irregular menstruation and premenstrual spotting. In congruence, with the above mentioned findings Bhattacharjee et al., (2014) his study about Clinical and non-clinical presentations of endometriosis, reported that the majority of the sample were exposed to menstrual symptoms in the form of hypermenorrhea, menorrhagia, premenstrual spotting for 2-4 days, mid cycle bleeding, irregular bleeding, and irregular periods.

It was obvious from the present result that almost two thirds of the participants had no children and the majority suffered from infertility which lasted between 3-15 years.

This is matching with the finding of Culley et al., study (2013) about improving the wellbeing of people living with endometriosis, who found that, most women with endometriosis have difficulty in getting pregnant, $71 \%$ of them have tried to conceive and $90 \%$ had difficulties in the experience. They added that infertility is reported as a concern, which results in depression and feelings of inadequacy among women, as well as uncertainty about future fertility, contributing to the breakdown of a relationship.

History of genital tract infection and adhesions were also encountered among the studied sample and surgical therapy was mostly conducted. This is in congruence with Lin et al., (2016) who demonstrate that genital tract inflammation/ infections increase the risk of endometriosis. NesbittHawes \& Ledger, study (2015) in a proposed focus on deep dyspareunia, added that the major pelvic adhesions or peri-tubal adhesions can explain infertility in patients with severe forms of endometriosis. Meanwhile, De Graaff et al., (2013) reported that women with endometriosis frequently underwent more than one surgery (mean 2.2 surgeries).

The most pronounced complaint of the present studied women with endometriosis is pain, which can be expressed in a variety of symptoms including dysmenorrhea, dyspareunia, chronic pelvic pain, dysuria and dyschezia. The high prevalence of symptoms in the present study is consistent with the results from two earlier studies in considerably smaller cohorts of women with 
chronic endometriosis patients who frequently reported both dysmenorrhea (71-94\%) and dyspareunia (32-70\%) (Fagervold et al., 2009; Tripoli et al., 2011). They added that these symptoms cause profound ill health and significant reduction in women quality of life.

According to Meurs-Szojda et al., study (2011) about Irritable bowel syndrome and chronic constipation in patients with endometriosis women with endometriosis commonly experience gastrointestinal symptoms, which include; abdominal pain, bloating, nausea, constipation, vomiting, painful bowel movements, and diarrhea. Meanwhile, cyclic related bloating, constipation, passage of mucus in the stools and cyclical rectal bleeding were also encountered among women with endometriosis. Moreover, Somigliana et al., (2007) reported that urogenital tract involvement occur in almost $10-15 \%$ of patients with endometriosis. This include; frequency, urgency, supra-pubic pain, dysuria and a positive correlation between the severity of dysuria and lesion diameter has been noticed. The above mentioned finding was partially close to the results of the current study.

The present study finding revealed that the delay between the start of symptoms until diagnosis ranged from two months to 10 years, with women already experiencing severe symptoms. Most women reported visiting a variety of health professionals and undergoing a whole range of tests, but without being diagnosed with endometriosis. They were not satisfied with the treatment they received and more than three quarters of the studied women had insufficient knowledge about endometriosis.

This correspond well with the finding of Moradi et al., (2014) who found that the average delay to diagnosis ranged from three months to 24 years with an average of 8.1 years. They added that in some cases, they were misdiagnosed and mistreated for appendicitis, ovarian cyst, ectopic pregnancy, pelvic inflammatory disease, and ovarian cancer.

Meanwhile, Nnoaham et al., study (2011) across ten countries about impact of endometriosis on quality of life and work productivity reported that there was a delay of 6.7 years, principally in primary care, between onset of symptoms and a surgical diagnosis of endometriosis, which was longer in centers where women received predominantly state-funded health care ( 8.3 vs. 5.5 years).

Delay was positively associated with the number of pelvic symptoms (chronic pelvic pain, dysmenorrhea, dyspareunia, and heavy periods) and a higher body mass index. In this respect Manderson et al., (2008) mentioned that the delay in the diagnosis and treatment of endometriosis because women were not believed by doctors, family, friends and colleagues. Some were angry, frustrated and annoyed at being labeled inappropriately (e.g. suffering from sexually transmitted infections) and misunderstood. Women's ideas of menstrual pain as 'normal' were shared by some doctors, and their families, resulting in further delay before a definitive diagnosis was made. 
Recently, Facchin et al., (2015) reported that the women normalized their severe period pain or other symptoms and did not take their symptoms seriously. They and their doctors misdiagnosed or mistreated them because they did not believe them, or they lacked knowledge. Difficulty accessing a gynecologist and long surgery waiting lists were reported by participants, and these also contributed to a delay in diagnosis. Some women reported that they resorted to self-diagnosis because of a known family history, information from the internet or informed friends, and interaction with other patients with endometriosis.

Mendes and Figueiredo, (2012) added that most women were dissatisfied for not being given enough information at the time of diagnosis. Some women reported that the doctors' lack of information about diagnosis of endometriosis cause a delay in the diagnosis.

It was obvious from the present results that the majority of the studied patients had a negative impact on their physical life. Physical limitations in terms of; body movement, anorexia, doing home- work, taking care of their children because of pain, was noticed sometimes and frequently in most of the studied sample. This is in congruence with Fourquet., study (2011) who found that $61.0 \%$ of women with endometriosis experience difficulties with mobility, daily activities and/or self-care. Meanwhile, $58.0 \%$ experience increased sleeping disturbances and $45.0 \%$ showed a negative impact on their childcare. In addition, Nnoaham, (2011) found in a cross-sectional study in 10 countries that women with endometriosis had reduced physical health compared with the normative population.

It was also noticed in the current study that endometriosis had a negative impact on the psychological life of the studied women. Almost three quarters felt frustrated because their symptoms are not getting better, being inadequate and depressed at the possibility of not having children as well as had the feeling of depression, anxiety and feelings of low self-esteem. In the same line Simoens et al., (2012) showed that endometriosis symptoms negatively impact patient psychological well-being. Among Quality of Life domains, the more commonly affected factors were changes in mood, sadness, and the feeling of being incomplete, which were reported by more than half of respondents.

Similarly, Moradi et al., (2014) found that most women experience feeling upset, angry, depressed, uncertain, weak, powerless, helpless, hopeless, defeated, disappointed, frustrated, exhausted, and felt like a burden to others. A negative effect on self-esteem, self-confidence and lack of control of their life (powerlessness) were other reported psychological impacts.

In this regard reported that having endometriosis, although asymptomatic, implies living with a chronic disease that affects the "core" of femininity, as it may involve sexual problems, as well as the risk of infertility. The mere awareness of having endometriosis may be associated with negative 
feelings (e.g. being "different", being sick, being an "incomplete" woman) as well as depressionlike behavior and sadness). A possible explanation of the above findings could be due to the fact that the psycho-neuro-immune nature of the disease may enhance women's perception of depressive symptoms and distress; acute and chronic stress, depression and anxiety may negatively affect the immune system with the development of a vicious circle of inflammation, sickness behavior and depression (Nasyrova et al., 2011).

According to Vercellini et al., study (2011) dyspareunia associated with endometriosis has been announced as a research priority by the World Endometriosis Society, which called it a 'neglected aspect' of endometriosis. It limits sexual activity which result in a lowering of self-esteem and a negative effect on relationships. Women had feelings of guilt or inadequacy regarding the avoidance of sex, and partners felt rejected, jeopardized or broke up relationship.

Consistent with the present study, a comparable association between affected sexual life and lower quality of life score was revealed in a population of women experiencing infertility. Many of them experienced significant problems with their partner due to endometriosis and some of them considered endometriosis as a cause of their divorce (Chachamovich et al., 2009 and De Graaff et al., 2013).

Meanwhile, Fourquet et al., (2011) reported that endometriosis negatively affected women sexual lives, the majority were suffered usually or sometimes from the feeling of guilty or frustration because of avoiding intercourse or being unhappy with it.

The negative impact of endometriosis on women's educational life was present in more than three fourths of the present studied women. This was mostly noticed in the variables of taking frequent sick leaves, poor concentration and carrying out school duties. Meanwhile, endometriosis had a great negative impact on women's work lives. Nearly three quarters of them had sometimes or usually take time off work because of pain, causing women to feel guilty and embarrassed because of loss productivity.

Conversely, the impact on education appeared to be less pronounced, in De Graaff1, study (2013), since only $16.0 \%$ of the responding women indicated that they lost significant time of their education due to endometriosis-associated symptoms. This might be caused by the fact that the mean reported age at first symptoms is 24 years at which time most women have finished their formal education. In contrast, the effect of endometriosis on work was clearly noteworthy with $51.0 \%$ of 
women stating that endometriosis significantly affected their job at some time during their life. A possible explanation of the discrepancy between the above finding and the present one could be due to the difference in sample size, design as well the criteria of patient selection.

In one previous study on 78 women diagnosed with endometriosis 15 years prior to the study, women reported that in this 15-year period, $8.5 \%$ suffered from an affected education, $49.3 \%$ had impaired work ability, $15 \%$ had serious problems in their relationships and $7.7 \%$ suffered from a broken relationship due to the symptoms of endometriosis (Fagervold et al., 2009).

In another study of 107 women with previous surgery for endometriosis, work was affected in $66.0 \%$ (Fourquet et al., 2010). A focus on the impact of endometriosis on education has been included in a small number of papers with inconclusive findings. Whilst some studies reported that endometriosis had affected women's study activity and grades, and had caused some to leave education before completion (Huntington et al., 2005 \& Gilmour et al.,2008), others reported that only a minority of women had experienced negative consequences on their education (Fagervold et al., 2009) .

More commonly, researchers have explored how endometriosis has affected women's working lives. Several papers suggest that women's endometriosis symptoms, particularly pain symptoms, impact on productivity at work with between 23 and 66\% reporting limitations in their ability to perform work-related activities (Bernuit et al., 2011). This is in agreement with the current study finding where women were often unable to carry out duties at work because of the pain and they felt guilty toward this. The majority of them felt embarrassed about symptoms at work. In this respect Fourquet et al., (2011) reported that $84-85 \%$ of women described a decrease in their quality of work with an average rate of work impairment and reduced effectiveness of $65 \%$ (presenteeism) and an average loss of efficiency levels of $64.0 \%$ (work productivity loss). Also, Moradi et al., (2014) reported that a negative effect of endometriosis related symptoms on employment was the main issue discussed by studied women in their study. Having endometriosis led them to take time off work, choose part-time work, made them less productive, whilst some had to give up their favorite job or lost the chance of promotion.

In addition, El-Maraghy et al., (2017) revealed that endometriosis has a significant negative impact on work productivity and Health Related Quality of Life of affected Egyptian women, leading to high economic burden and huge costs to society.

The results of this study points to a statistically significant relation between stages of endometriosis and the negative aspect of women's quality of life in terms of physical, psychological, sexual, educational and working life. This agree with Nnoaham etal., (2011) and Siedentopf et al.,(2008) who reported that advanced rAFS stages were negatively influence work productivity and 
Health Related Quality of Life. In contrast, Marques et al. reported that women with advanced stages of endometriosis scored better on mental health and emotional role limitation domains (Marques et al., 2004).

\section{CONCLUSION:}

\section{Based on study findings, it can be concluded that:}

This study provided tangible evidence of the negative impact of endometriosis on important aspects related to physical, psychological, sexual, educational and working life. In addition, there is statistically significance relation between stages of endometriosis and the negative aspect of women's quality of life. This study pointed to the delay in seeking treatment that ranged between 210 years and even most of them were not satisfied with the treatment and had insufficient knowledge about the problem and how to cope with it.

\section{RECOMMENDATIONS:}

\section{Based on the results of the present study, the following recommendations were suggested:}

The nursing and medical care provided for women with endometriosis should address the physical, emotional, sexual and social problems that come with the disease besides continuation of improving surgical techniques and medical therapy.

$\square$ Teaching patients to avoid the delay in seeking treatment. As well as how to cope with chronic pelvic pain, to explore ways to have sexual intercourse without pain and to teach patients how to strengthen relationships with their partner and friends so they will be supportive in coping with the disease instead of drifting apart due to potential misunderstandings.

There is a need for a large comprehensive study addressing the quality of life in a prevalent group of women with endometriosis, because existing studies have small sample sizes, are treatment related or examine only newly diagnosed patients.

\section{REFERENCES:}

Adamson, G. D. (2016). Endometriosis: Medical and Surgical Management of Pain and Infertility.

International Federation of Gynecology and Obstetrics, 1-50.

Bernuit, D., Ebert, A. D., Halis, G., Strothmann, A., Gerlinger, C., Geppert, K., \& Faustmann, T. (2011). Female perspectives on endometriosis: findings from the uterine bleeding and pain women's research study. Journal of Endometriosis, 3(2), 73-85. 
Bhattacharjee, P. P., Sathiaraj, G. D., Zaid, M., Gatti, J. R., Lee, C., Tsai, C. W., \& Yeh, J. W. (2014). Microstructure and texture evolution during annealing of equiatomic $\mathrm{CoCrFeMnNi}$ high-entropy alloy. Journal of Alloys and Compounds, 587, 544-552.

Callahan, T., \& Caughey, A. B. (2013). Blueprints obstetrics and gynecology (Vol. 6). Lippincott Williams \& Wilkins.

Chachamovich, J., Chachamovich, E., Fleck, M. P., Cordova, F. P., Knauth, D., \& Passos, E. (2009). Congruence of quality of life among infertile men and women: findings from a couplebased study. Human reproduction, 24(9), 2151-2157.

Culley, L., Law, C., Hudson, N., Denny, E., Mitchell, H., Baumgarten, M., \& RaineFenning, N. (2013). The social and psychological impact of endometriosis on women's lives: A critical narrative review. Human Reproduction Update, 19(6), 625-639. https://doi.org/10.1093/humupd/dmt027 accessed at 1/2018

De Graaff, A. A., D’hooghe, T. M., Dunselman, G. A. J., Dirksen, C. D., Hummelshoj, L., Simoens, S., ... Wullschleger, M. (2013). The significant effect of endometriosis on physical, mental and social wellbeing: Results from an international cross-sectional survey. Human Reproduction, 28(10), 2677-2685. https://doi.org/10.1093/humrep/det284

Denny, E., \& H Mann, M. C. (2007). A clinical overview of endometriosis: a misunderstood disease. British journal of nursing, 16(18), 1112-1116.

Dunselman, G. A. J., Vermeulen, N., Becker, C., Calhaz-Jorge, C., D’Hooghe, T., De Bie, B., ... others. (2014). ESHRE guideline: management of women with endometriosis. Human Reproduction, 29(3), 400-412.

El-maraghy, M., Labib, K., \& Salah, W. (2017). The Impact of Endometriosis Symptoms on Health Related Quality of Life and Work Productivity in Egypt, 4(3).

Facchin, F., Barbara, G., Saita, E., Mosconi, P., Roberto, A., Fedele, L., \& Vercellini, P. (2015). Impact of endometriosis on quality of life and mental health: pelvic pain makes the difference. Journal of Psychosomatic Obstetrics \&Gynecology, 36(4),135-141.

https://doi.org/10.3109/0167482X.2015.1074173 accessed at 1/2018 
Fagervold, B., Jenssen, M., Hummelshoj, L., \& Moen, M. H. (2009). Life after a diagnosis with endometriosis - A 15 years follow-up study. Acta Obstetricia et Gynecologica Scandinavica, 88(8), 914-919. https://doi.org/10.1080/00016340903108308 accessed at 2/2018

Gao, X., Outley, J., Botteman, M., Spalding, J., Simon, J. A., \& Pashos, C. L. (2006). Economic burden of endometriosis. Fertility and Sterility, 86(6), 1561-1572.

Huntington, A., \& Gilmour, J. A. (2005). A life shaped by pain: women and endometriosis. Journal of Clinical Nursing, 14(9), 1124-1132.

Lin, W.-C., Chang, C. Y.-Y., Hsu, Y.-A., Chiang, J.-H., \& Wan, L. (2016). Increased Risk of Endometriosis in Patients With Lower Genital Tract Infection. Medicine, 95(10), e2773. https://doi.org/10.1097/MD.0000000000002773 accessed at 2/2018

Manderson, L., Warren, N., \& Markovic, M. (2008). Circuit breaking: pathways of treatment seeking for women with endometriosis in Australia. Qualitative Health Research, 18(4), $522-534$.

Mamdouh, H. M., Mortada, M. M., Kharboush, I. F., \& Abd-Elateef, H. A.-E. (2011). a hospital-based case--contrEpidemiologic determinants of endometriosis among Egyptian womenol study. The Journal Of The Egyptian Public Health Association, 86(1 and 2), 21-26.

Marques, A., Bahamondes, L., Aldrighi, J. M., \& Petta, C. A. (2004). Quality of life in Brazilian women with endometriosis assessed through a medical outcome questionnaire. The Journal of reproductive medicine, 49(2), 115-120.

Mendes, N., \& Figueiredo, B. (2012). Psychological approach to endometriosis: women's pain experience and quality of life improvement. Psicologia, Saúde e Doenças, 13(1), 36-48.

Meurs-Szojda, M. M., Mijatovic, V., Felt-Bersma, R. J. F., \& Hompes, P. G. A. (2011). Irritable bowel syndrome and chronic constipation in patients with endometriosis. Colorectal Disease, 13(1), 67-71.

Moradi, M., Parker, M., Sneddon, A., Lopez, V., \& Ellwood, D. (2014). Impact of endometriosis on womens lives: a qualitative study. BMC Women's Health, 14(1), 123.

Nasyrova, R. F., Sotnikova, L. S., Baystrukova, N. V, Krivoschchekova, G. V, Novitsky, V. V, Kupriyanova, I. E., ... Baykov, A. N. (2011). Psychoimmune interactions in women of 
reproductive age with endometriosis. Bulletin of Experimental Biology and Medicine, 152(1), 9397.

Nesbitt-Hawes, E. M., \& Ledger, W. (2015). Endometriosis and infertility. Reproductive Surgery in Assisted Conception, (June 2014), 29-35. https://doi.org/10.1007/978-1-4471-4953-8_3 accessed at $3 / 2018$

Nnoaham, K. E., Hummelshoj, L., Webster, P., dHooghe, T., de Cicco Nardone, F., de Cicco Nardone, C., ... Zondervan, K. T. (2011). Impact of endometriosis on quality of life and work productivity: a multicenter study across ten countries. Fertility and Sterility, 96(2), 366-373.

Rogers, P. A., D’Hooghe, T. M., Fazleabas, A., Giudice, L. C., Montgomery, G. W., Petraglia, F., \& Taylor, R. N. (2013). Defining future directions for endometriosis research: workshop report from the 2011 World Congress of Endometriosis in Montpellier, France. Reproductive sciences, 20(5), 483-499.

Siedentopf, F., Tariverdian, N., Rücke, M., Kentenich, H., \& Arck, P. C. (2008). Immune status, psychosocial distress and reduced quality of life in infertile patients with endometriosis. American Journal of Reproductive Immunology, 60(5), 449-461. https://doi.org/10.1111/j.1600-

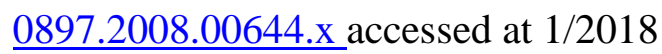

Simoens, S., Dunselman, G., Dirksen, C., Hummelshoj, L., Bokor, A., Brandes, I., ... others. (2012). The burden of endometriosis: costs and quality of life of women with endometriosis and treated in referral centres. Human Reproduction, 27(5), 1292-1299.

Somigliana, E., Vercellini, P., Gattei, U., Chopin, N., Chiodo, I., \& Chapron, C. (2007). Bladder endometriosis: getting closer and closer to the unifying metastatic hypothesis. Fertility and sterility, 87(6), 1287-1290.

Sourial, S., Tempest, N., \& Hapangama, D. K. (2014). Theories on the pathogenesis of endometriosis. International journal of reproductive medicine, 2014.

Tripoli, T. M., Sato, H., Sartori, M. G., de Araujo, F. F., Girão, M. J., \& Schor, E. (2011). Evaluation of quality of life and sexual satisfaction in women suffering from chronic pelvic pain with or without endometriosis. The journal of sexual medicine, 8(2), 497-503.

Vercellini, P., Meana, M., Hummelshoj, L., Somigliana, E., Viganò, P., \& Fedele, L. (2011). Priorities for endometriosis research: a proposed focus on deep dyspareunia. Reproductive Sciences, 18(2), 114-118. 
Wolman, I. (2014). Berek and Novak's Gynecology 15th Edition. The Journal of Obstetrics and Gynecology of India, 64(2), 150-151. https://doi.org/10.1007/s13224-014-0538-

\section{تأثير بطانة الرحم المهاجرة على جودة الحياة لاى السيدات في مراكز صحة الأم والطفل بدمياط}

أ.د / سناءعلي نور1، أ.م.د/. سهام شحاتة ابراهيم²، د/ جيهان أحمد البهلوان3، ولاء حدلي عبد اللطيف منتصر أستاذ تمريض النساء و التوليد ـ كلية التمريض ـ جامعة الزقازيق 1 ـ أستاذ مساعد تمريض الأمومة و النساء و التوليد ـ كلية

التمريض - جامعة بورسعيد 2ـ مدرس تمريض الأمومة و النساء و التوليد كلية التمريض- جامعة بورسعيد3

غالبا ما يوصف داء بطانة الرحم المهاجرة بأنه "المرض الضائع أو المفقود" فلا يوجد علاج له، عبئه الاقتصادي مرتفع ولا يوجد ما يضمن عدم عودنه مرة أخرى. تهدف هذه الدراسة إلى تقييم تأثير بطانة الرحم المهاجرة علي جودة حياة المرأة. أجريت هذه الدر اسة الوصفية من بداية ديسمبر 2016 إلى نهاية مايو 2017 في ثناث مر اكز لصحة الأم و الطفل بدمياط، وهم مركز صحة الأم و الطفل بدمياط الجديدة، شطا وكفر شحاتة. وقد اشتملت عينة البحث على (100) امر أة مصابة بمرض بطانة الرحم المهاجرة والمشخصة جر احيا. وقد تم جمع البيانات عن طريق استخدام؛ استبيان للسيدات واستبيان آخر خاص ببطانة الرحم المهاجرة لتقييم تأثيره على جودة الحياة. وكثفت النتائج أن عمر النساء اللاتي أجريت عليهن الدراسة بين (25 - 30) سنة من العمر ، الغالبية العظمى (83\%) منهن يعانين من العقم، وكان هناك تأخر في التماس العلاج الطبي لهذا المرض و الذي تراوح ما بين 2-10 سنة بالإضافة لوجود علاقة ذات دلالة إحصائية بين مر احل مرض بطانة الرحم المهاجرة و الجانب السلبي لنوعية حياة المر أة و المتمثلة في الحياة البدنية والنفسية والجنسية والتعليمية و العملية. وأوصت الدراسة بالحاجة إلى ضرورة تورة توعية وتعليم المرضي تجنبا للنأخر في التماس العلاج، وكذلك كيفية التعامل مع ألم الحوض المزمن بالإضافة، إلى كيفية تعزيز العلاقات مع شريكهم و أصدقائهم حتى يكونو ا داعمين لهن في التعامل مع هذا المرض. 